\title{
The assessment of computationally derived protein ensembles in protein-ligand docking
}

\author{
Barbara Sander ${ }^{1 *}$, Oliver Korb², Jason Cole ${ }^{2}$, Jonathan W Essex ${ }^{1}$ \\ From 7th German Conference on Chemoinformatics: 25 CIC-Workshop \\ Goslar, Germany. 6-8 November 2011
}

The inclusion of receptor flexibility in protein-ligand docking experiments has become a major research interest in drug discovery $[1,2]$. One of the possible methods applied is the use of multiple discrete protein conformations, so called ensemble docking [3,4]. With computational techniques like Molecular Dynamics (MD) a large number of different conformations can be generated, not all of which can or should be included in the docking or virtual screening process [5]. The question arises if and how suitable protein conformations can be selected systematically a priori based on quantifiable conformational features.

For neuraminidase and cyclin-dependent kinase II (CDK2), snapshots of MD simulation trajectories have been clustered based on different structural properties using a variety of clustering methods. To establish a possible correlation between docking performance and target conformational attributes the clustered snapshots have been subjected to extensive self- and cross-docking experiments as well as virtual screening using the GOLD docking programme. It is shown that conformationally similar snapshots do not necessarily result in a similar docking or virtual screening performance. The selection of the particular structural property on which to base the clustering appears to be the essential problem.

\section{Author details \\ 'School of Chemistry, University of Southampton, Highfield, Southampton, SO17 1BJ, UK. ${ }^{2}$ Cambridge Crystallographic Data Centre, 12 Union Road, Cambridge, CB2 1EZ, UK.}

Published: 1 May 2012

\section{References}

1. Carlson HA: Protein flexibility and drug design: how to hit a moving target. Curr Opin Chem Biol 2002, 6:447-452.

2. Durrant JD, McCammon JA: Computer-aided drug-discovery techniques that account for receptor flexibility. Curr Opin Pharmacol 2010, 10:770-774.

3. Barril X, Morley DS: Unveiling the full potential of flexible receptor docking using multiple crystallographic structures. J Med Chem 2005, 48:4432-4443.

4. Huang S-Y, Zou H: Ensemble docking of multiple protein structures: considering protein structural variations in molecular docking. Proteins 2007, 66:399-421.

5. Lin J-H, Perryman AL, Schames JR, McCammon JA: Computational drug design accomodating receptor flexibility: the relaxed complex scheme. J Am Chem Soc 2002, 124:5632-5633.

doi:10.1186/1758-2946-4-S1-P34

Cite this article as: Sander et al:: The assessment of computationally derived protein ensembles in protein-ligand docking. Journal of Cheminformatics 2012 4(Suppl 1):P34.

\footnotetext{
* Correspondence: bs3e09@soton.ac.uk

'School of Chemistry, University of Southampton, Highfield, Southampton, SO17 1BJ, UK
}

Full list of author information is available at the end of the article
Publish with ChemistryCentral and every scientist can read your work free of charge
"Open access provides opportunities to our colleagues in other parts of the globe, by allowing anyone to view the content free of charge."
W. Jeffery Hurst, The Hershey Company.
- available free of charge to the entire scientific community
- peer reviewed and published immediately upon acceptance
- cited in PubMed and archived on PubMed Central
- yours - you keep the copyright
Submit your manuscript here:
http://www.chemistrycentral.com/manuscript/

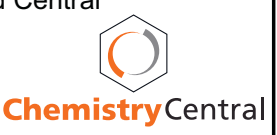

